\title{
Xanthine Oxidase Inhibitory Activity of Tetracera Indica
}

\author{
Fauziah Abdullah $^{1, *}$, Nor Hadiani Ismail ${ }^{3}$, Fadzureena Jamaludin ${ }^{2}$ and Siti Nur Aisyah Mohd \\ Hashim $^{2}$ \\ ${ }^{I}$ Phytochemistry Programme, ${ }^{2}$ Bioactivity Programme, Natural Products Division, Forest Research Institute Malaysia \\ (FRIM) 52109 Kepong, Selangor, Malaysia \\ ${ }^{3}$ Faculty of Applied Sciences, University Teknologi Mara, Shah Alam, 40450 Shah Alam, Selangor, Malaysia
}

\begin{abstract}
Preliminary screening study revealed that the methanolic extract of the stem of $T$. indica showed xanthine oxidase inhibitory activity in a concentration-dependent manner. EA fraction was selected to be further study due to its potential to inhibit xanthine oxidase enzyme with $\mathrm{IC}_{50}$ value of $21.14 \mu \mathrm{g} / \mathrm{ml}$ which in lower than $\mathrm{IC}_{50}$ value of $\mathrm{MeOH}$ extract, $42.02 \mu \mathrm{g} / \mathrm{ml}$. Further separation and purification of EA fraction led to the isolation of two known compounds. Those compounds were identified by analysis of their spectroscopic data and comparisons with literature data to be betulinic acid and 5,7-dihydroxyl-8-methoxyflavone.
\end{abstract}

Keywords: Tetracera indica, xanthine oxidase.

\section{INTRODUCTION}

Xanthine oxidase $(\mathrm{XO})$ is a key enzyme that catalyzes the last step in the conversion of purines to uric acid, and plays a vital role in producing hyperuricemia and gout [1]. Allopurinol, the medication prescribed for gout prevention, is a xanthine oxidase inhibitor [2]. However, due to unwanted side effects of allopurinol, new alternatives with fewer side effects are desired. In folk remedies, leaves of Tetracera indica Merr. (Dilleniaceae) are effectively used in the treatment of diabetes and anti-inflammatory related diseases. Some studies have proven scientific evidence for the traditional use of leaves of $T$. indica in the management of diabetes in Malaysia. However, there is no scientific claim about its efficacy in the treatment of anti-inflammatory related diseases [3]. Based on literature, Tetracera spesies are widely used for the treatment of anti-inflammatory related diseases. Therefore, the aim of this study is to investigate potential anti-inflammatory activity of $T$. indica via xanthine oxidase inhibitory assay. Our preliminary screening study revealed that the methanolic extract of the stem of $T$. indica showed xanthine oxidase inhibitory activity in a concentration-dependent manner.

\section{MATERIALS AND METHODOLOGY}

\subsection{Plant Material}

The stem of $T$. indica was purchased from Intan Gaharu Sdn. Bhd. in October 2011 and was identified by Miss Tan Ai Lee, Bio resources Programme, Natural Product Division, Forest Research Institute Malaysia. A voucher sample of the

*Address correspondence to this author at the Phytochemistry Programme, Natural Products Division, Forest Research Institute Malaysia (FRIM) 52109 Kepong, Selangor; Tel: +603-6279 7361; Fax: +603-6272 9805;

E-mail: fauziahabdullah@frim.gov.my aerial part has been deposited at the Herbarium of Forest Research Institute Malaysia

\subsection{Extraction and Isolation}

The dried stem of $T$. indica was extracted with methanol $(\mathrm{MeOH})$, the $\mathrm{MeOH}$ solution was evaporated under pressure to give a $\mathrm{MeOH}$ extract $\left(73.6 \mathrm{~g} ; \mathrm{IC}_{50} 42.02 \mu \mathrm{g} / \mathrm{ml}\right)$. The $\mathrm{MeOH}$ extract was suspended in water $\left(\mathrm{H}_{2} \mathrm{O}\right)$ and partitioned successively with hexane, (dichloromethane) DCM, and (ethyl acetate) EA to yield hexane $\left(1.89 \mathrm{~g} ; \mathrm{IC}_{50}>100\right.$ $\mu \mathrm{g} / \mathrm{ml}), \mathrm{DCM}\left(2.78 \mathrm{~g} ; \mathrm{IC}_{50}>100 \mu \mathrm{g} / \mathrm{ml}\right)$, EA (3.80 g; $\mathrm{IC}_{50}$ $21.14 \mu \mathrm{g} / \mathrm{ml})$ and aqueous $\left(59.17 \mathrm{~g} ; \mathrm{IC}_{50} 35.36 \mu \mathrm{g} / \mathrm{ml}\right)$ fractions, respectively. EA fraction was selected to be further study due to its potential to inhibit xanthine oxidase enzyme with $\mathrm{IC}_{50}$ value of $21.14 \mu \mathrm{g} / \mathrm{ml}$ which in lower than $\mathrm{IC}_{50}$ value of $\mathrm{MeOH}$ extract, $42.02 \mu \mathrm{g} / \mathrm{ml}$.

The EtOAc fraction $(3.89 \mathrm{~g})$ was subjected to Medium Pressure Liquid Chromatography (MPLC) using Injection Column of silica gel $70 \mu \mathrm{m}, 14 \mathrm{~g}$, size $\mathrm{M}(20 \times 75 \mathrm{~mm})$ and Hi-Flash Column of silica gel $40 \mu \mathrm{m}, 120 \mathrm{~g}$, size $3 \mathrm{~L}(46 \mathrm{x}$ $130 \mathrm{~mm})$ eluted with $\mathrm{CHCl}_{3}-\mathrm{MeOH}(0-100 \%)$ to give 11 fractions. Fraction 4 was white crystal of betulinic acid (1, $0.10 \mathrm{mg}$ ) [4]. Fraction 6 was light yellow powder of 5,7dihydroxyl-8-methoxy-flavone $(2,0.03 \mathrm{mg})$ [5].<smiles>CC(=O)C12CCC3C(CCC4C5(C)CCC(C)CC5CCC34C)C1CC(C)(C)CC2</smiles>

(1) 
<smiles>COc1cc(O)c(O)c2c(=O)cc(-c3ccccc3)oc12</smiles>

(2)

Betulinic acid (1) White crystal, ${ }^{1} \mathrm{H}-\mathrm{NMR}\left(\mathrm{CDCl}_{3}-\right.$ $\left.\mathrm{CD}_{3} \mathrm{OD}, 300 \mathrm{MHz}\right) \delta: 0.73(3 \mathrm{H}, \mathrm{s}, \mathrm{H}-25), 0.83(3 \mathrm{H}, \mathrm{s}, \mathrm{H}-23)$, 0.95 (3H, s, H-24), 0.98 (3H, s, H-27), 1.38 (3H, s, H-26), $1.68(3 \mathrm{H}, \mathrm{s}, \mathrm{H}-30), 3.03$ (2H, t, H19), 4.68 (1H, dd, H-3) $4.78(3 \mathrm{H}, \mathrm{s}, \mathrm{H}-29),{ }^{13} \mathrm{C}-\mathrm{NMR}\left(\mathrm{CDCl}_{3}-\mathrm{CD}_{3} \mathrm{OD}, 300 \mathrm{MHz}\right)$ $\delta$ : 15.1 (C-27), 15.8 (C-24), 16.3 (C-25), 16.5 (C-26), 18.9 (C-6), 21.5 (C-11), 26.2 (C-12), 27.4 (C-2), 28.3 (C-23), 30.3 (C-21), 31.2 (C-15), 32.9 (C-16), 35. (C-22), 37.7 (C7), 37.8 (C-10), 39.0 (C-13), 39.4 (C-4), 39.5 (C-1), 43.1 (C8), 43.3 (C-14), 47.7 (C-18), 49.8 (C-19), 51.3 (C-9), 56.2 (C-5), 56.9 (C-17), 79.2 (C-3), 113.5 (C-29), 154.9 (C-20), 183.4 (C-28).

\section{5,7-dihydroxyl-8-methoxyflavone (wogonin) (2) light yellow powder}

NMR spectrum $\left(\mathrm{CDCl} 3-\mathrm{CD}_{3} \mathrm{OD}, 300 \mathrm{MHz}\right) \delta: 3.18$ (3H, s, OCH3), $6.16(1 \mathrm{H}, \mathrm{s}, \mathrm{H}-3), 6.60(1 \mathrm{H}, \mathrm{s}, \mathrm{H}-6), 7.47$ $(3 \mathrm{H}, \mathrm{m}, \mathrm{H}-3,4,5), 8.04$ (2H, d, J = 8.0, H-2,6), $12.99(1 \mathrm{H}, \mathrm{s}$, $5-\mathrm{OH}) .{ }^{13} \mathrm{C}-\mathrm{NMR}\left(\mathrm{CDCl}_{3}-\mathrm{CD}_{3} \mathrm{OD}, 300 \mathrm{MHz}\right) \delta: 62.9(\mathrm{C}-$ 8), 100.5 (C-6), 105.1 (C-3), 105.7 (C-10), 127.2 (C-2', C5'), 129.3 (C-8), 130.3 (C-3', C-5'), 132.3 (C-1'), 133.0 (C4'), 151.2 (C-7), 159.3 (C-5), 165.2 (C-2), 183.8 (C-4)

\subsection{XO Inhibitory Assay}

Xanthine oxidase inhibiting activity was conveniently measured by slightly modifying the spectrometric method developed by Nuki 2006 [6]. In assay protocol, $130 \mu 1$ of $0.05 \mathrm{M}$ potassium phosphate buffer $(\mathrm{pH} 7.5), 10 \mu 1$ of testcompound solution and $10 \mu \mathrm{l}$ of xanthine oxidase enzyme solution were mixed and incubated for $10 \mathrm{~min}$ at $25^{\circ} \mathrm{C}$. The reaction was then initiated by the addition of $100 \mu l$ xanthine (substrate) solution. The enzymatic conversion of xanthine to form uric acid and hydrogen peroxides measured at absorbance of $295 \mathrm{~nm}$. Test compounds and reference standards were dissolved in DMSO. All reactions were performed in triplicates in a 96-well UV microplate

\section{RESULT AND DISCUSSION}

The dried stem of T. scandens was extracted with $\mathrm{MeOH}$, the $\mathrm{MeOH}$ solution was evaporated under pressure to give a $\mathrm{MeOH}$ extract. The $\mathrm{MeOH}$ extract was suspended in $\mathrm{H}_{2} \mathrm{O}$ and partitioned successively with hexane, $\mathrm{CH}_{2} \mathrm{Cl}_{2}$, and EtOAc to yield hexane, $\mathrm{CH}_{2} \mathrm{Cl}_{2}$, EtOAc, and $\mathrm{H}_{2} \mathrm{O}$ fractions. Among them, the EtOAc fractions showed strong $\mathrm{XO}$ inhibitory activity with $\mathrm{IC}_{50}$ values of $\mathrm{IC}_{50}$ value of 21.14 $\mu \mathrm{g} / \mathrm{ml}$. EA fraction was selected to be further study due to its potential to inhibit xanthine oxidase enzyme with $\mathrm{IC}_{50}$ value of $21.14 \mu \mathrm{g} / \mathrm{ml}$ which in lower than $\mathrm{IC}_{50}$ value of $\mathrm{MeOH}$ extract, $42.02 \mu \mathrm{g} / \mathrm{ml}$. Further separation and purification of EA fraction led to the isolation of two known compounds. Those compounds were identified by analysis of their spectroscopic data and comparisons with literature data to be betulinic acid (1) [4] and 5,7-dihydroxyl-8-methoxyflavone (2) [5].

\section{CONCLUSIONS}

In this paper, we have reported xanthine oxidase inhibitory activity in a concentration-dependent manner of $\mathrm{MeOH}$ crude extract, hexane, DCM, EA and $\mathrm{H} 2 \mathrm{O}$ fractions of $T$. indica. $\mathrm{MeOH}$ extract and EA fraction showed xanthine oxidase inhibitory activity in a concentration-dependent manner. Interstingly, betulinic acid (3) - a naturally occurring pentacyclic triterpenoid which has been shown to exhibit avariety of biological activities including inhibition of human immunodeficiency virus (HIV), antibacterial, antimalarial, antiinflammatory, anthelmintic and antioxidant properties [7], was found in high yield from this plant. These results suggested that the traditional use of $T$. indica for the treatment of rheumatism and inflammatory diseases may be attributable to the XO inhibitory activity of lupane triterpene and flavonoid constituents.

\section{CONFLICT OF INTEREST}

The authors confirm that this article content has no conflicts of interest.

\section{ACKNOWLEDGEMENTS}

This work was supported by ESFund from Ministry of Agriculture, Malaysia. We thanked Ms. Tan Ai Lee and staff of Taman Ethnobotani for collecting and providing the plant materials

\section{REFERENCES}

[1] Borges, F.; Fernandes, E.; Roleira, F. Progress towards the discovery of xanthine oxidase inhibitors. Curr. Med. Chem., 2002, 9, 195-217.

[2] Oettl, K.; Reibnegger, G. Protein structure and molecular. Acta, 1999, 1430, 387-395.

[3] Do, T.L. Vietnamese Medicinal Plant. Hara, S., Okabe, H., Mihashi, K. Gas-liquid chromatography separation of aldose enantiomers as trimethylsilyl ethers of methyl 2(polyhydrocyalkyl)-thiazolidine-4(R)-carboxy-lates. Chemical and Pharmaceutical Bulletin, Hanoi: Medicine Publisher, 1987; vol. 35, pp. 501-506.

[4] Shashi, B.M.; Asish, P.K. 13C NMR Spectra of pentacyclic triterpenoids - a compilation and some salient features, Phytochemistry, 1994, 37(6), 1517-1575.

[5] Harrison, L.J.; Sia, G.L.; Sim, K.Y. 5,7-Dihydroxy-8methoxyflavone from Tetracera indica. Planta Med., 1994, 60(5), 493-494.

[6] Nuki, G. Gout. Medicine, 2006, 34(10), 417-423.

[7] Yogeeswari, P.; Sriram, D. Betulinic acid and its derivatives: a review on their biological properties. Curr. Med. Chem., 2005, 12(6), 657-66. 